\title{
The Finance \& Its Impact on Economic Development in SUDAN Assessment Study: (2011-2018)
}

Dr. AbdelrahmanTahir Hag Adam*

Assistant Professor, PhD Holder in Economics Sciences, Almadain College for Medical Sciences \& Technology

Article History
Received: 11.10 .2020
Accepted: 28.10 .2020
Published: 04.11 .2020
Journal homepage:
https://www.easpublisher.com/easjebm
Quick Response Code

Abstract: This Preliminary Development Finance Assessment (DFA) comes at a key
moment for Sudan as we look towards the 2030 Agenda by aiming to achieve the
ambitious Sustainable Development Goals. To translate this vision into action requires
concrete and comprehensive strategies, including in relation to the mobilization and use
of finance. This preliminary DFA provides evidence and analysis towards articulating
the finance sources for Sudan and looks generally at how the country can make better use
of existing finance, while not losing sight of the need to identify new avenues of
mobilizing additional resources. The Addis Ababa Action Agenda, which emerged from
the third International Conference on Financing for Development 2015 emphasized the
need for countries to take a more integrated approach to managing all types of finance,
by improving integration across government, as well as between government and other
stakeholders. The preliminary DFA for Sudan makes preliminary observations towards
this end. And the committed to implement policy frameworks that will contribute to
increased mobilization of public resources and unlock the potential of the private sector
and the civil society to finance development, in collaboration with our development
partners. We are also committed to review our institutional arrangements for more
integrated use of resources. Efforts will be complemented by up-scaled and more
effective international assistance to overcome the structural challenges we face. While
the preliminary DFA recommendations outline an ambitious agenda, to look forward to
collaborating with our partners on further articulating these observations. As we look
ahead to the challenges of mobilizing and managing a range of different types of finance
in pursuance of the country's development priorities, this type of intra-governmental
collaboration will be critical, especially as Sudan looks towards the achievement of the
SDGs. Finally, I am hopeful that the Government, together with relevant stakeholders,
will be able to benefit from this assessment.

Keywords: Sustainable Development, mobilization, Financing, utilizing, infrastructure, Assessment.

Copyright $\odot$ (2020 The Author(s): This is an open-access article distributed under the terms of the Creative Commons Attribution 4.0 International License (CC BY-NC 4.0) which permits unrestricted use, distribution, and reproduction in any medium for non-commercial use provided the original author and source are credited.

\section{INTRODUCTION}

Financing is a kingpin for the accomplishment of the new Sustainable Development Agenda, which is driven by the implementation of the 17 Sustainable Development Goals (SDGs), necessitating momentous investments estimated at trillions of dollars. The cost of financing the achievement of the SDGs goes well beyond the resources currently existing for most countries. Meeting these investment requirements will entail the mobilization of a variety of substantial supplementary resources. It will also involve utilizing and guiding resources efficiently and coherently, and countries must plan to finance their SDGs from public and private, domestic and international resources. Meeting this challenge will require countries to take a comprehensive approach to financing for development. The Addis Ababa Action Agenda (AAAA) of 2015 called for 'cohesive nationally owned sustainable development strategies supported by an Integrated
National Financing Framework (INFF) to be at the heart of these efforts'. The AAAA and the follow-up 2017 report of the Inter-Agency Task Force on Financing for Development therefore call for the establishment of holistic and forward-looking financing frameworks that consider the ever-expanding diversity of development resources. The INFF can be understood as a system of policies and institutional structures designed to enable governments to take a comprehensive approach towards mobilizing and managing financing for national development strategies. In response to demands from governments to reflect on the changing development cooperation landscape and the call to establish INFFs, the Development Finance Assessment (DFA) tool was developed by the United Nations Development Programmed, it functions as a country-level, contextinformed methodology that provides data and analytical information on both quantitative and qualitative aspects of development resources in a country. The DFA tool 
provides not only an overall mapping of financing flows, but also looks at an enabling environment for accessing, allocating, utilizing, and monitoring the variety of financing available to a country. The assessment process is nationally owned and aimed at offering the national development partners with data and analysis on changing trends in development finance and their alignment with national priorities and results.

\section{Purpose of the Preliminary Development Finance Assessment for Sudan \\ This Preliminary Development Finance} Assessment (DFA) for Sudan was undertaken under the guidance of the State Minister of the Ministry of International Cooperation (MIC), H.E. Somia Okoued, in collaboration with the UN Resident Coordinator's Office2. The UN Resident Coordinator's Office commissioned independent experts to undertake this assessment looking at financing for development in view of Sudan's commitment to the SDGs. The purposes of this preliminary DFA document are therefore to:

1. Present the concepts of the DFA within the context of Sudan as to enable the promotion of a potential undertaking of a full nationally-led DFA when further data and resources are made available.

2. Offer recommendations for the scope of a potential comprehensive DFA, which looks at all financing flows and the structural environment for the establishment of an INFF.

3. Showcase the trends, challenges, and opportunities pertaining to the main financing flows in Sudan within the private/public and domestic/external quadrants throughout the years of 2011-2016.

4. Provide a preliminary baseline analysis for the establishment of an INFF for Sudan.

\section{Financing for Development in Sudan}

Sudan is at an important juncture for setting its path to achieve sustainable development and to implement its state reform programme. Linked to this is the recent establishment of the "National Mechanism to Supervise the Sustainable Development Goals", which is a high-level coordination mechanism that oversees the progress of achieving the SDGs. The prospective national programme for sustainable development 20162030 aims to provide the essential foundation for the country's endeavour to achieve the SDGs. Furthermore, the lifting of US sanctions on Sudan in 2017 has induced a change in the country's economy and resource base for financing the national programme for sustainable development, hence creating opportunities to deepen engagement in the international economy to explore new sources of financing.

Combined with the strong Government of Sudan (GoS) commitment to the 2030 Agenda and the SDGs, this is a vital moment to assess the variety of funding available to the country and work towards a holistic and integrated approach to financing the SDGs.

\section{Scope, Methodology and Data Collection}

This preliminary DFA reviews the main development finance flows and expenditures:

- Public revenue, including tax and non-tax revenue;

- Official Development Assistance (ODA);

- Remittance flows;

- Zakat revenues;

- $\quad$ Foreign Direct Investment (FDI); and

- $\quad$ Private-Public Partnerships (PPP).

This preliminary DFA examines, to the extent possible, how development finance flows have changed during the period 2011-2016 and what future trends are likely to be. It studies the policy and institutional framework relating to each source of development finance and identifies constraints on their effective mobilization, or use, and opportunities for optimization. The assessment is done at the national level, with some exploration of the agriculture sector, which has been identified as a SDGs accelerator. The assessment also looks at the role of PPP in infrastructure and their contribution to the enabling environment for development.

The methodology used for the assessment includes extensive stakeholder consultations through bilateral meetings, in addition to a kick-off workshop organized in November 2017 and a follow up review workshop in February 2018, which was facilitated by the Ministry of International Cooperation and the National Technical Committee for the DFA (chaired by MIC). The participants in the workshops and bilateral interactions also included members of the private sector, civil society organizations, and development organizations. Official data was collected from a range of GoS agencies such as MIC, Ministry of Finance and Economic Planning (MoFEP), the Central Bank of Sudan (CBoS), Ministry of Investment, Ministry of Agriculture, Central Bureau of Statistics (CBS), and the Zakat Chamber.

GoS policies and strategic planning frameworks were analyzed and used together with studies conducted by development partners, namely the Organization for Economic Co-operation and Development (OECD) and the International Monetary Fund (IMF). Some comparison was made to the experience of other countries that have recently completed a similar assessment, particularly Nepal, although their experience is not fully documented yet. It is noted that data shortages and quality issues are perennial problems that this study faced. While aggregate figures are available for most sources of development finance, some of the disaggregated data by sector, or geographical area, is unavailable. 


\section{Sudan Country Context}

The secession of South Sudan in 2011 triggered severe economic shocks, largely due to the loss of oil revenue that accounted for over half of Sudan's revenue and $95 \%$ of its exports, leading to high inflation and reduced economic growth. Since then, the GoS has taken notable steps to contain the fiscal deficit, reduce inflation, and strengthen overall public financial management resulting in increased economic stability and growth in recent years. Although economic stabilization efforts have borne some fruits, large imbalances persist. The external account deficit remains large due to lower exports, while the fiscal deficit also remains high because of low revenues unaccompanied by adequate expenditures rationalization; and growth remains below potential.

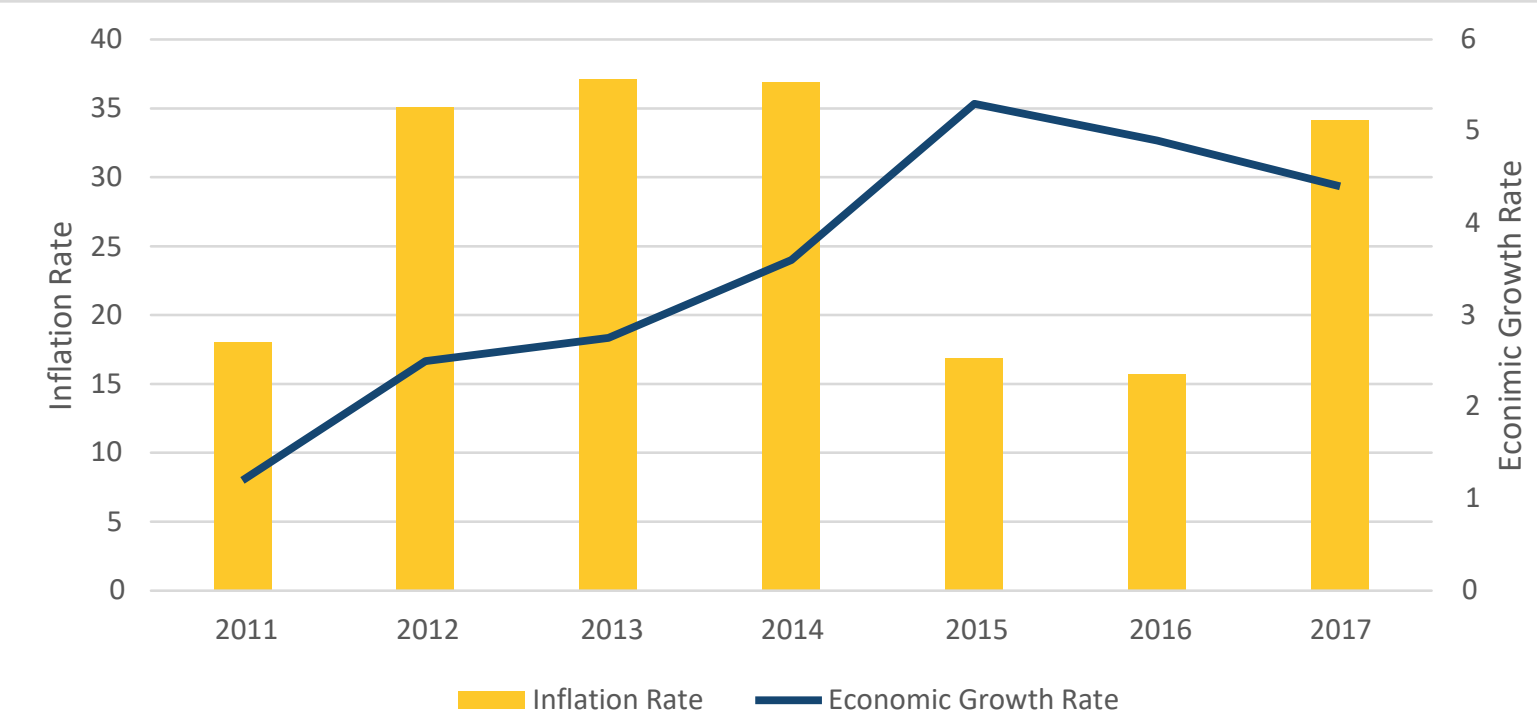

Fig-1: Growth and Inflation Rates (2011-2017) (in \%)

Note: Amounts in nominal values.

Source: Growth rate from annual budget performance reports and average annual inflation rate calculated from monthly average inflation rate from the Central Bureau of Statistics.

\section{External Debt Burden}

Sudan remains in debt distress and is eligible for debt relief under the Heavily Indebted Poor Countries (HIPC) Initiative. Public and external debt remains unsustainably high with most external debt in arrears. The external debt, as percentage of GDP, is also growing with the pace of depreciation of the Sudanese Pound (SDG); the debt reached SDG 45.4 billion or $40 \%$ of GDP at the end of 2016.5 .
The external debt portfolio in Sudan is characterized by the increasing share of arrears, which is representing $87 \%$ of the total debt on average. This increase was mainly caused by weak repayments and the accumulated penalty interest. Despite the relative decrease in principal and interest arrears, the share of total arrears in total external debt is still considerably high as illustrated in Tables 1 and 2 below.

Table 1: Total Arrears of External Debt (2011-2015) (in million USD and as \% of Total External Debt)

\begin{tabular}{|l|l|l|l|l|l|}
\hline Item / Year & $\mathbf{2 0 1 1}$ & $\mathbf{2 0 1 2}$ & $\mathbf{2 0 1 3}$ & $\mathbf{2 0 1 4}$ & $\mathbf{2 0 1 5}$ \\
\hline Total Debt (in million USD) & $\mathbf{3 9 , 8 0 0}$ & $\mathbf{4 2 , 0 4 9}$ & $\mathbf{4 4 , 3 7 9}$ & $\mathbf{4 3 , 6 6 0}$ & $\mathbf{4 3 , 8 8 4}$ \\
\hline Total Arrears (in million USD) & $\mathbf{3 3 , 9 5 6}$ & $\mathbf{3 6 , 3 0 7}$ & $\mathbf{3 8 , 5 4 5}$ & $\mathbf{3 8 , 1 7 5}$ & $\mathbf{3 8 , 2 5 0}$ \\
\hline Total Arrears (as \% of Total External Debt) & $\mathbf{8 5 \%}$ & $\mathbf{8 6 \%}$ & $\mathbf{8 7 \%}$ & $\mathbf{8 7 \%}$ & $\mathbf{8 7 \%}$ \\
\hline \% Growth of Total Arrears & $\mathbf{4 \%}$ & $\mathbf{7 \%}$ & $\mathbf{6 \%}$ & $\mathbf{- 1 \%}$ & $\mathbf{0 . 2 \%}$ \\
\hline
\end{tabular}

Note: Amounts reflected in nominal terms.

Source: Central Bank of Sudan, 15th Annual Report on Sudan External Debt (2015).

Table-2: Composition of Arrears in External Debt (2011-2015) (in \%)

\begin{tabular}{|l|l|c|c|c|c|}
\hline Item / Year & $\mathbf{2 0 1 1}$ & $\mathbf{2 0 1 2}$ & $\mathbf{2 0 1 3}$ & $\mathbf{2 0 1 4}$ & $\mathbf{2 0 1 5}$ \\
\hline Principal Arrears & $\mathbf{3 1 \%}$ & $\mathbf{3 1 \%}$ & $\mathbf{3 2 \%}$ & $\mathbf{3 0 \%}$ & $\mathbf{3 0 \%}$ \\
\hline Interest Arrears & $\mathbf{1 2 \%}$ & $\mathbf{1 2 \%}$ & $\mathbf{1 1 \%}$ & $\mathbf{1 2 \%}$ & $\mathbf{1 1 \%}$ \\
\hline Penalty Arrears & $\mathbf{5 7 \%}$ & $\mathbf{5 7 \%}$ & $\mathbf{5 7 \%}$ & $\mathbf{5 8 \%}$ & $\mathbf{5 9 \%}$ \\
\hline Total Arrears & $\mathbf{1 0 0 \%}$ & $\mathbf{1 0 0 \%}$ & $\mathbf{1 0 0 \%}$ & $\mathbf{1 0 0 \%}$ & $\mathbf{1 0 0 \%}$ \\
\hline
\end{tabular}

Source: Central Bank of Sudan, 15th Annual Report on Sudan External Debt (2015). 


\section{Overview of Development in Sudan}

Sudan is witnessing transformations that are affecting its development; rapid urbanization, rapid population growth, and exponential increase in the number of adults in the 25 to 64 working age are examples of these transformations. By 2030, the year by which the SDGs should be achieved, Sudan will have more working age adults (23 million) than children (20 million), and a huge group of youth aged 15 to 24 (11 million). By 2075 there will be two adults in the working age for every one child aged below 15.6.

During the term of the Millennium Development Goals (MDGs) between 2000 and 2015, Sudan did not fully achieve any of the MDGs, but made considerable progress in the areas of universal primary education, promoting gender equality, empowering women, reducing child mortality, and combating HIV/AIDS, malaria and other diseases. By the end of 2015, areas which were requiring further efforts included ones on eradicating extreme poverty and hunger, improving maternal health, ensuring environmental sustainability, and developing global partnerships for development. In general, the progress in meeting the MDGs targets was constrained by the lack of sufficient domestic and external resources.

Measuring progress in achieving specific MDGs provides evidence for social sector programming and the formulation of the prospective Poverty Reduction Strategy Paper (PRSP). According to the 2014 Multiple Indicator Cluster Survey (MICS), access to improved sanitation remained low at $33 \%$, one of the lowest rates in Sub-Saharan Africa.8 In Sudan the overall prevalence of child malnutrition is high; onethird $(33 \%)$ of under-five children are underweight. That being said, access to improved drinking water sources stood at $68 \%$, an improvement from $64 \%$ in 1990. There have also been improvements in access to and use of maternal and child health services, as seen for example in the increased coverage of antenatal care from $74 \%$ in 2006 to $79 \%$ in 2014 . Moreover, underfive mortality rates declined from 112 per 1,000 live births in 2006 to 83 per 1,000 live births in 2010 and further to 68 per 1,000 live births in 2014 , half the level in 2006. Infant mortality rates decreased by about $60 \%$ between 2006 and 2014 from 83 per 1,000 live births in 2006 to 34 per 1,000 live births in 2014. In education, the literacy rate for women aged between 15 and 24 years increased from $45 \%$ in 2010 to $60 \%$ in 2014, with advancements made in terms of schooling. In 2014, the primary school attendance ratio was $76 \%$ with a completion rate of $79 \%$. The primary school gender parity index saw a positive trend, increasing from 0.93 in 2010 to 0.98 in 201410. However, improved social indicators at the national level are masked by wide disparities among the states that need to be addressed.

During the period from 2011 to 2016 Sudan faced adverse conditions with regards to the ability of the Government to reduce poverty. For example, the combined difficulties of economic shock created by the loss of oil revenues due to the secession of South Sudan, the conflict within South Sudan, and the decline in international oil prices. The absence of debt relief in addition to consistent low levels of concessional financing and the US economic sanctions were also notable challenges. Such constraints have had an opposing impact on economic stability, trade, banking, business climate, private sector economic activity, employment, and consequently, poverty reduction.

The Interim Poverty Reduction Strategy Paper (I-PRSP) Status Report from 2016 found that, despite a decline in overall expenditure, public resources allocated to the I-PRSP pillars, with the view of targeting the poor, grew from $4.2 \%$ to $5 \%$ of GDP between 2012 and 2014. The I-PRSP pillars are: (i) promoting economic growth and employment creation, focusing on agriculture and infrastructure; (ii) developing human resources, emphasizing education, health and social protection; (iii) reintegrating internally displaced persons and other displaced populations; and (iv) strengthening governance and institutional capacity of the public sector, focusing on human rights, peace and security, decentralization and public financial management.

\section{Poverty in Sudan}

Findings of the recently launched 2014 Sudan Household Budget and Poverty Survey presented the poverty rate in Sudan at $36.1 \%$, ranging between $12.2 \%$ in the Northern state and $50.4 \%$ in the East Darfur state. One in four Sudanese citizens $(25 \%)$ falls below the extreme poverty line, with unemployment being a major cause of poverty in Sudan. While individuals living in households with unemployed heads of households represent only $2.4 \%$ of the total population, they account for $50 \%$ of the population living below the poverty line. Inequality has decreased over time, and in 2014 the share of the poorest quintile in consumption was $8.9 \%$, up from $6.2 \%$ in 2009 .

Results from the 2014 Poverty Survey also show that annual per capita consumption in Sudan was SDG 6,082 with urban areas displaying average annual per capita consumption levels higher than in rural areas (SDG 7,149 and SDG 5,509 respectively). Annual food consumption per capita in Sudan was estimated at SDG 3,636 . Food was the main category of expenditure and accounted for $60 \%$ of total consumption, with significant differences between urban and rural areas (53\% and $64 \%$ respectively).

\section{Security and Conflict Situation in Sudan}

One of the challenges facing development in Sudan is persistent conflicts; the situation is now steady, but the root causes that led to the conflicts need to be addressed. Armed conflict has subsided following the Eastern Sudan Peace Agreement in 2006 and the 
Doha Darfur Peace Agreement (DDPD) in 2011. The security situation in Darfur is stable, a reality reflected by the African Union/United Nations Hybrid Operation in Darfur's (UNAMID) second phase of its reconfiguration, which include further reductions in its personnel. The Government of Sudan's implementation of the compulsory phase of the weapons collection campaign that started in August 2017 was successful and contributed to an improved overall security situation and promoted peace in the country. The ceasefire and cessation of hostilities, which have brought significant benefits to the people of the Two Areas of Blue Nile and South Kordofan, are sustained. With the facilitation of the African Union High-Level Implementation Panel (AUHIP), the Government and the Sudan People's Liberation Movement-North (SPLM-N) continue to negotiate, with the resolve to explore ways of addressing the outstanding issues in order to achieve a lasting peace in the Two Areas. Furthermore, the final status of Abyei area is not yet resolved. The two governments of Sudan and South Sudan have not agreed yet to the establishment of institutions in the area, and the border is disputed. The negotiations were halted due to the eruption of civil war in South Sudan. The status of the Abyei area poses a potential risk of increased tensions. Moreover, there are risks associated with instability resulting from migration of populations and refugee flows from neighboring countries. The large number of migrants and refugees exert considerable pressures on hosting communities leading to devastating economic, social, and environmental impacts. Addressing instability is essential, given the wide regional disparities in development and social services in the country, as instability influences resource allocation in both national and state budgets, further constraining development and deepening disparities which are root causes of conflicts.

Inequalities in allocation of public resources and in access to natural resources are believed to be the main drivers of conflict and feeds into the ethnic divide. In Eastern Sudan the signing of the Eastern Sudan Peace Agreement in 2006 led to the creation of a Special Fund for Rehabilitation and Development of Eastern Sudan as an implementation mechanism. Moreover, the "International Donors and Investors Conference for East Sudan" was organized in Kuwait in December 2010 to support the development process in the region. Out of the total pledges of USD 3.5 billion in the conference, major pledges were made by GoS (USD 1.5 billion), Kuwait (USD 500 million), and the Islamic Development Bank (IsDB) (USD 250 million).

Another important peace agreement is the 2011 DDPD. More than 150 countries, international financial institutions, development organizations, and international non-governmental organizations participated in the "International Donor Conference for Reconstruction and Development" in 2013. Pledges towards the Darfur Development Strategy mainly came from GoS's commitment of USD 2.6 billion (as part of the DDPD agreement) and Qatar's contribution of USD 500 million.

\section{Sudan's Ongoing Efforts Towards 2030}

The Government's 2030 vision set through the Twenty-Five Year National Strategy 2007-2031 provides a foundation for the country's efforts for sustainable development and poverty reduction. The Government has initiated work towards mainstreaming the SDGs by means of a presidential decree to formulate national mechanisms to supervise the implementation of the SDGs. The "National Mechanism to Supervise the Sustainable Development Goals", with the National Population Council (NPC) as its secretariat, includes all relevant stakeholders for monitoring progress on achieving the SDGs. The national mechanism is expected to play a crucial role in coordinating and pursuing the entire government to achieve the SDGs. The NPC led the drafting of the National Programme for Sustainable Development 2016-2030. This national programme is in its draft form and reviews the lessons learned from the MDGs era. It also presents mechanisms and proposes priority pillars for 2017-2020 for SDGs implementation, and maps the existing national policies, strategies, plans as well as ministries and agencies, which are relevant to the SDGs. Through consultations with relevant stakeholders, the national programme for sustainable development will need to be endorsed at the level of the Council of Ministers.

Although data and national statistical capacities need to be enhanced, Sudan shows a particular commitment to the follow-up and review of the 2030 Agenda and the SDGs. Currently, NPC and the CBS are reviewing the framework of indicators for Sudan's SDGs. CBS in partnership with the United Nations Population Fund finalized a mapping of data availability against the SDGs in 2017. Also, a new round of the MICS will be conducted in 2019 to assess progress on key indicators on the well-being of children and women making use of the MICS 2014 as a baseline. At the global level, Sudan signed up for the Voluntary National Review at the High-Level Political Forum on Sustainable Development in 2018 to present the progress in SDGs. In addition, GoS plans to produce thematic and biannual SDGs reports.

\section{Financing the SDGs}

Financing the SDGs for Sudan requires amassing a mix of finance; international and national, public and private. A strategic approach for financing the SDGs is to be overseen by the National SDGs Implementation Coordination Mechanism as well as relevant stakeholders. Furthermore, with declared economic reforms, a rise in economic growth may indicate increased financing opportunities for the SDGs. 
Nevertheless, addressing issues such as economic policy reforms, high population growth, fluctuation and depreciation of exchange rates, and high (albeit decreasing) inflation rates are important for the utilization of this growth. Moreover, there is a need to further diversify the economy and increase trade and levels of tax collection. Domestic private finance shows good potential, especially through PPPs and corporate social responsibility (CSR). Zakat, under domestic public finance, also represents an important development financing flow given that it targets the most vulnerable population groups. In regard to international public flows, the greater amount of foreign aid is currently being directed to humanitarian programmes, in addition to development loans and grants. The lifting of sanctions may allow donors to access more development financial tools and instruments, although this will take time, especially for any eventual debt relief. Recently, only nonDevelopment Assistance Committee (DAC) donors such as the United Arab Emirates (UAE) and Kuwait have increased funding levels.

A better understanding of resource utilization and allocation means matching financial tools and instruments to the SDGs framework's priorities and timelines. This includes understanding current and pipeline ODA flows, any projected influxes of private investment that may follow the lifting of sanctions, how to make the best use of remittances, domestic resources (tax), and how they can all be allocated for social, economic and environment development. In this context, reviewing the federal budgeting system to enable further knowledge about the synergies between the national SDGs priorities and allocated resources is an important process for building a coherent SDGsbased national financing strategy for development.

\section{Development Planning Framework}

Before Sudan endorsed the SDGs, GoS organized national consultations with various stakeholders (government, private sector, civil society, state level) around the post-2015 development agenda. The consultations were led by the NPC, covered eleven states and included a national workshop for civil society organizations and the private sector, and a national consultation workshop in Khartoum. The national consultations fed into the preparation of a national consultation paper on the Post-2015 development agenda.

The national strategic planning in Sudan is based on the Twenty-Five-Year Strategic Plan 20072031. The plan is divided into five consecutive plans; currently, it is in the third plan (a four-year plan for 2017-2020), which is guiding development planning in the country. This third plan has been produced after consultations at the federal level and the states (the national plan and the state plans compose the general development plan for the country). The consultations were also undertaken with development sectors and considered the action plans and priority areas for the sectors. The directives for formulating the 2017-2020 plans included the mainstreaming of the SDGs in national development planning. With data being very critical for the plan, the CBS is positioned as a member of the Higher Committee for Strategic Planning. Generally, strategic planning could be strengthened through better articulated frameworks of goals, targets and indicators.

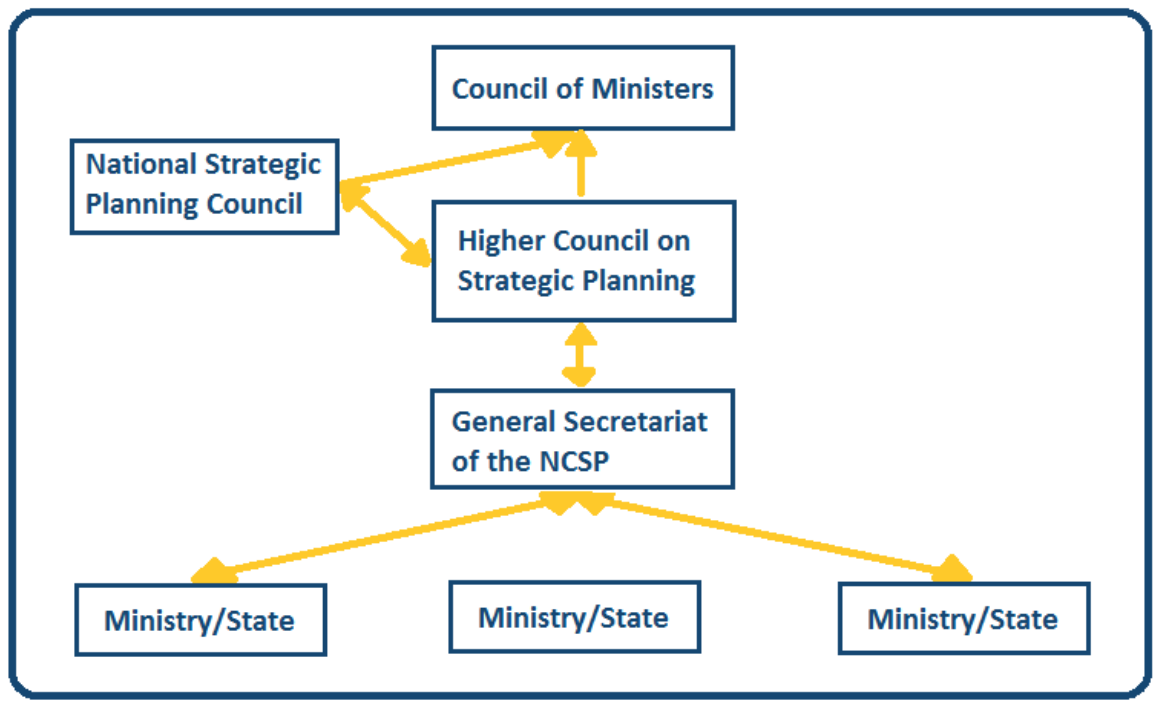

Fig-2: Monitoring Framework for the Five-Year Strategic Plan

Source: National Council for Strategic Planning, the Sudan National Strategic Plan (2007-2011) (2007).

\section{Costing for the Strategic Plan Implementation}

Financing of development in Sudan is guided by medium-term and long-term plans. The Government formulated a three-year emergency economic recovery programme for 2012-2014 called the "Salvation Economic Programme" aligned to the Twenty-Five- 
Year Strategic Plan. Afterwards, the Government developed the 2015-2019 five-year plans "Programme for Economic Reforms". Sudan has also developed an IPRSP and is currently preparing the PRSP, which will be based on the published results of Sudan Household Budget and Poverty Survey of 2014.

GoS undertakes annual costing for the medium term-plans in its annual budget. Sudan has made reasonable progress in implementing a well observed budget calendar underpinned by an adequate policy framework and statutory and regulatory framework at federal and state levels. The budget process is typically triggered by the "Federal Budget Circular", which is set out in consultation with the Secretary of the National Council for Strategic Planning (NCSP). The circular gives a general guidance on policy priorities and macroeconomic outlooks and is sent out in late August to all government entities. Thereafter, government units submit their proposals and discuss them with the MoFEP within the policy framework specified in the circular. The budget is then discussed by the technical committees of the Cabinet (undersecretaries) and, after that, by the ministerial economic committees (ministers) and subsequently discussed and approved by the Cabinet. Subsequently, the President will submit the budget to the National Assembly, which will discuss it and then pass the budget into law (as the New Year budget law). This procedure takes place by the end of the December prior to the beginning of the new financial year on 1 January.

States follow a similar process with the circular issued by the State Ministry of Finance guided by the circular of the MoFEP. Proposals are discussed by the State Ministry of Finance with the states units and, after approval; the budget is formulated and submitted to the State Council of Ministers. The budget, once approved by the State Council of Ministers, is tabled before the State Legislative Council, which will debate it. Once amended and agreed upon, the state budget will pass into law as the New Year budget law starting on 1 January. The state budget on the resource side includes states' own revenues (tax) and transfers from the federal government (both current and development).

The UN Country Team has partnered with GoS in organizing two international SDGs Mainstreaming, Acceleration and Policy Support (MAPS) missions to Sudan, the first in December 2016 and the latest one in October 2017, to advise on the process of mainstreaming SDGs in national development plans and the development of a national SDG framework. The report and recommendations of the 2017 MAPS mission have not been released yet, but they will be of great relevance in advising the processes of costing and financing SDGs in Sudan.

\section{Overall Financing Overview}

A kick-off workshop for the preliminary DFA was organized in November 2017, included members of the DFA National Technical Committee and gathered scoping recommendations on the financing flows with potential for financing development (to be used by both the preliminary and potential DFA at varying degrees). The identified flows are in the public/private and domestic/international aspects of the financial landscape in Sudan. The participants in the workshop collectively populated Table 3 below with quadrants representing the aforementioned aspects of the financial landscape.

Table-3: The Quadrants of Sudan Financing Landscape

\begin{tabular}{|c|c|c|}
\hline & Public & Private \\
\hline Domestic & $\begin{array}{l}\text { - Taxes (including Customs) } \\
\text { - Non-Tax Revenues } \\
\text { - States' own (Tax) Revenue } \\
\text { - Zakat } \\
\text { - Investic Finance (Government Musharaka and } \\
\text { - Social Security Investment Authority } \\
\text { - Insurance Funds }\end{array}$ & $\begin{array}{ll}\text { - } & \text { Corporate Social } \\
& \text { Responsibility } \\
\text { - } & \text { Public-Private Partnership } \\
\text { - } & \text { Domestic Credit (including } \\
& \text { Microfinance) } \\
\text { - } & \text { Informal Sector }\end{array}$ \\
\hline External & $\begin{array}{l}\text { - Official Development } \text { Assistance }^{17} \text { from } \\
\text { Bilateral/Multilateral: } \\
\text { i. Loans } \\
\text { ii. Technical Cooperation } \\
\text { iii. Project Grants } \\
\text { iv. Other Official Flows } \\
\text { v. South/South Cooperation }\end{array}$ & $\begin{array}{ll}\text { - } & \text { Remittances } \\
\text { - } & \text { Foreign Direct Investment } \\
\text { - } & \text { Private Sector Windows in } \\
\text { International and Regional } \\
\text { Finance Institutions }\end{array}$ \\
\hline
\end{tabular}

Source: UN RCO, "Internal Report on Kick-Off Workshop of Preliminary DFA" (November 2017).

Although the workshop listed the above flows as potential means for development finance, this preliminary DFA is discussing only some of these flows due to the preliminary nature of the study, the relatively short timeline for conducting the preliminary DFA, and data availability factors. Moreover, data could not be collected for flows other than the ones analyzed in this assessment. It is also worth mentioning that the kick-off 
workshop for the preliminary DFA recommended that the amounts in this report should be reflected in SDG. Data for ODA, FDI and remittances was received in USD; data for all other flows in this report was received and reflected in SDG. Furthermore, all amounts of all flows in this report (whether received in SDG or USD) are in nominal terms.

An overview of development financing flows in Sudan is provided. Domestic finance as well as tax and non-tax revenue are two major sources of finance in Sudan. A potential comprehensive DFA should also analyses the flows of domestic credit from banks to the private sector in terms of their development impact.

\section{Domestic Public Finance}

With the secession of South Sudan in 2011, three quarters of Sudan's oil output, which was the main source of foreign currency and government income, were lost. The global oil price slump in 2015 exacerbated the situation of low oil revenue. Apart from oil revenue, Sudan has deposits of other metals and minerals, but these deposits are under-exploited. Generally, there have been major investments aimed at supporting diversification of the economy.

Domestic financing as percentage of GDP is expected to increase20, while tax and non-tax revenue remains the dominant sources of funding in GoS's budget.

Tax includes such items as income and profit tax, property tax, tax on goods and services (VAT), and tax on international trade (customs). Non-tax revenues include revenues from state-owned enterprises, goods and services sales, sales of goods from government corporations, oil revenue, administrative charges, fines, penalties and confiscations, oil transit fees, and Transitional Financial Arrangements from South Sudan. Indirect taxes, out of the total tax revenues, represented $92.1 \%$ in $2015,92.3 \%$ in 2016 , and $92.9 \%$ in 2017 .

\section{Tax and Non-Tax Revenue}

Tax on goods and services constitutes more than half of the total tax revenue, and is projected to increase. Sudan's tax revenue is among the lowest for Low Income Countries and Lower-Middle Income Countries, making up only $5.3 \%$ of GDP in 2017, compared to an average of $16.8 \%$ of GDP in SubSaharan Africa. Corporate income tax revenue (as \% of GDP) was $0.4 \%$ in Sudan, with a Sub-Saharan Africa average of $2.5 \%$. Despite efforts to strengthen the tax administration, tax revenues have increased only marginally in recent years, and revenues from tax on personal income and tax on corporate income remain low.

Before the secession of South Sudan in 2011, Sudan's heavy reliance on oil concealed many of the deficiencies of the tax system. The weak revenue effort in the country can be attributed to several factors. Sudan applies excessive exemptions that greatly eroded the tax base. These exemptions apply to almost all types of taxes, including the business profit tax, VAT, taxes on international trade, and personal income tax. The growing informal sector and subsistence sectors, estimated to claim $60 \%$ of the economic activities, are outside the tax umbrella. A sector with high contribution to GDP, such as agriculture, which constitutes around $32 \%$ of GDP, has had a zero tax rate since 2001 and is outside the umbrella of the VAT and business profit tax. About $60 \%$ of goods and services are also exempted from the VAT, including animal products, private education, private health, drugs and pharmaceutical goods, electricity, and financial and insurance services. The upper margin for business and profit tax was reduced from $35 \%$ in 2007 to $15 \%$ to this date, while it ranges between $25 \%$ and $30 \%$ in the African countries. Taxes are also affected by the impact of Sudan's membership in the Common Market for Eastern and Southern Africa and the Arab Free Zone.

As such, there is significant potential to implement tax reform in Sudan to mobilize substantial resources, including reforms such as broadening the tax base and improving administration, strengthening tax and customs policy and administration, rationalizing tax exemptions, and improving the quality and availability of tax-related information. Oil revenues, which averaged 8\% of GDP from 1995 to 2011, have historically financed the bulk of GoS expenditure. However, after the secession of South Sudan in 2011, these revenues dropped to an average of $2.2 \%$ of GDP between 2012 and 2015, and are expected to continue to drop due to low global oil prices.

Table-4: Regional Comparison with Sudan of Central Government Tax Revenue (\% of GDP)

\begin{tabular}{|l|l|l|l|l|l|}
\hline & $\begin{array}{l}\text { Total Tax } \\
\text { Revenue }\end{array}$ & $\begin{array}{l}\text { Personal } \\
\text { Income Tax }\end{array}$ & $\begin{array}{l}\text { Corporate } \\
\text { Income Tax }\end{array}$ & $\begin{array}{l}\text { Goods and } \\
\text { Services Tax }\end{array}$ & $\begin{array}{l}\text { International } \\
\text { Trade Tax }\end{array}$ \\
\hline Sudan & 5.3 & 0.1 & 0.4 & 3.4 & 1.4 \\
\hline Sub-Saharan Africa & 16.8 & 2.7 & 2.5 & 3.6 & 4.2 \\
\hline Middle East \& Central Asia & 12.7 & 1.7 & 3.5 & 3.2 & 1.2 \\
\hline
\end{tabular}

Source: International Monetary Fund, "Sudan Staff Report for the 2017 Article VI Consultation" (September 2017).

Several reforms are being undertaken by the MoFEP to streamline expenditures and create fiscal space for spending on SDGs-related priorities, such as basic service delivery and poverty reduction. The MoFEP started reforming its budget planning by automating the budget management. It has adopted the 
Treasury Single Account for efficient use of available resources in the budget. The government budgeting system is becoming more transparent and the budget classification, according to Government Finance Statistics, introduced a functional classification for the first time in the 2018 budget. The objective of the functional classification, as stated in the budget document, is to detail the economic and social targets that the various government institutions strive to attain given the resources allocated to them in the budget. The new budget is also increasingly comprehensive. For 2018, the budget covered all government entities and institutions undertaking government operations, and presented a consolidated and complete view of these operations. The budget covers the federal government, state governments, social security investment funds, and higher education institutions. The ministry plans to move to programme budgeting soon. These reforms will contribute to a more integrated approach for government resources. Yet, more reforms in streamlining government spending will be needed during the coming period.

\section{States' Own Revenues (Tax)}

Sudan adopted the federal system of governance in 1992 with three tiers: federal, state, and local. States and localities were assigned certain expenditure responsibilities by the constitution, such as basic education, primary health, water supply, etc. The amended Interim National Constitution of 2005 granted state governments the right to legislate for raising revenue collection through a variety of local taxes and charges for services provided by the state. According to Article 195 of The Interim National Constitution, states were given the authority to legislate for raising revenue or collecting taxes from the following sources: (i) state land and property tax, and royalties; (ii) service charges for state services; (iii) licenses; (iv) state personal income tax; (v) levies on tourism; (vi) state government projects and national parks; (vii) Stamp duties; (viii) agricultural taxes; (viii) excise duties; and (ix) border trade charges or levies in accordance with national legislation.

The Interim National Constitution in Article 196(a) also assigned to localities the following tax sources: (i) real estate's proceeds; (ii) sales tax; (iii) agricultural and animal production tax; (iv) local land and river means of conveyance fees; (v) local industrial and crafts production fees; (vi) local services for mining fees; and (vii) any other local resources.

State tax collections are weak due to state-level tax policies, poor administration, and weak tax base (with variation among states). Considerable reform is required to boost the state taxes, which could constitute a major source of finance for improved basic services delivery.

\section{Government Musharaka Certificates}

Government Musharaka Certificates, also known as Shahama, are issued in registered form by the MoFEP through auctions to finance the budget. They are based on Musharaka financing modality (sharing of profit) with a one-year renewable maturity at the Government's option. There is a nominal value of each certificate and their profits are distributed annually. The return on Government Musharaka Certificates is based on the return from underlying projects and capital gains derived from re-evaluations of project assets. The clients for the certificates are the commercial banks, private companies, and the public. The certificates are traded in the Khartoum Stock Exchange Market and are considered high yielding certificates.

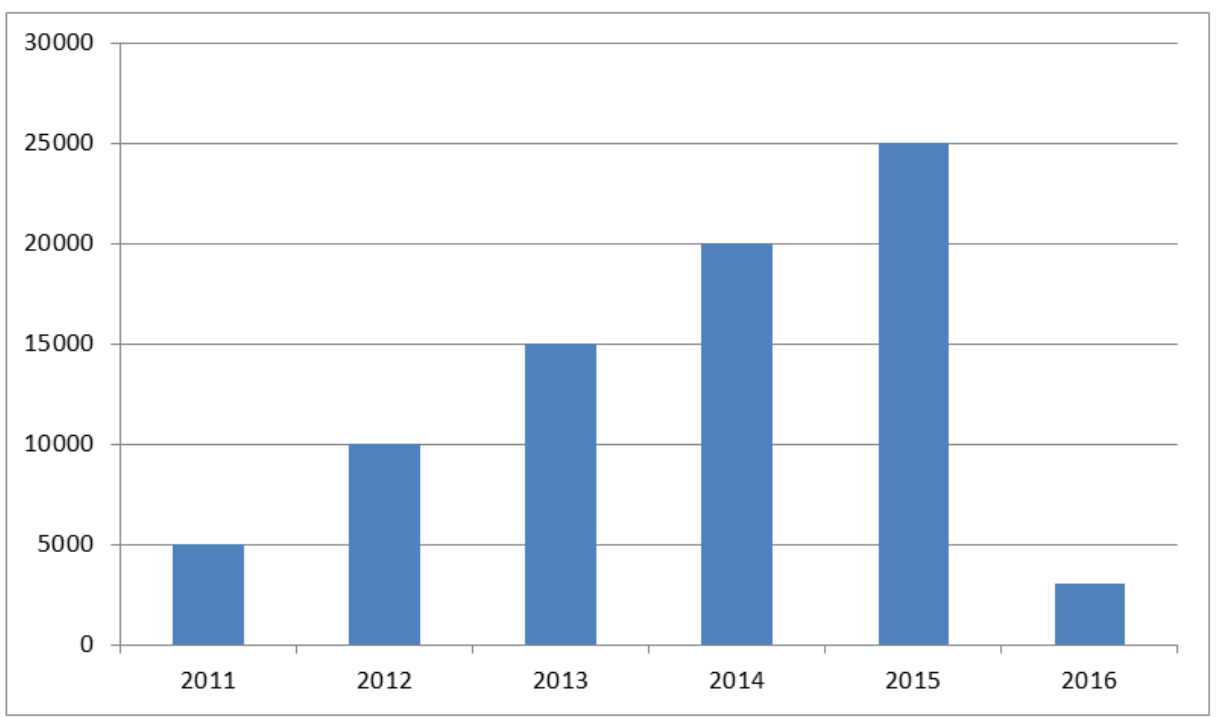

Fig-3: Value of Sold Musharaka Certificates (years in million SDG) Note: Amounts in nominal values.

Source: Central Bank of Sudan, Annual Reports (2011-2016). 
Zakat

The Zakat Chamber is responsible for collecting and distributing Zakat to groups of people from the population who are poor and vulnerable. Zakat is usually strengthening social protection efforts since its beneficiaries include poor and vulnerable groups. While Zakat is spent on the eight known religious categories of beneficiaries, it is worth mentioning that the category of "In the Cause of Allah" is used to cover activities that can be used for various development related activities, such as disarmament, demobilization and reintegration. Zakat is mandatory in Sudan and in 2016, the Zakat collection totaled around SDG 2,574 million.

The amounts collected from Zakat are increasing annually and are projected to continue growing in the coming years. The amounts of Zakat allocation to the poor and needy beneficiaries represent the bulk of Zakat allocations and are projected to continue being the bulk of the total allocation in the future. There is a significant potential for Zakat to reinforce its role in economic empowerment of the poor and needy through developing its capacities in economic empowerment and strengthening its synergies with national economic empowerment programmes and interventions (such as cash transfers to the poor). There is also a significant potential for Zakat to reinforce its development impact through capacity development, exchange of lessons learned, and harmonization between the targeting systems of Zakat and the aforementioned economic empowerment initiatives.

A Presidential Decree (No. 322), issued on 3 July 2004 established the Social Security Investment Authority (SSIA) to manage the surplus of the National Pension Fund and the National Social Insurance Fund. The SSIA statement advocates for the promotion and advancement of the national economy through its various investments. SSIA is currently investing its resources in agriculture, industry, financial services, medical fields, tourism and hotels, and real estate.

\section{Domestic Private Finance}

Domestic credit from banks is a flow with potential for financing development in Sudan. The extent to which domestic credit and domestic private investment contribute to development will need more data and research on where the financed investment is made (see Table-5). More analyses are also needed on the degree of control the Government has on reorienting domestic private finance flows and the extent of alignment of the current domestic investment patterns with the SDGs and national development goals and targets.

Table-5: Domestic Credit Flows, Financing from Commercial Banks to Private Sector (2011-2016) (in million

\begin{tabular}{|c|c|c|c|c|c|c|}
\hline \multicolumn{7}{|c|}{ SDG) } \\
\hline Year / Economic Sector & 2011 & 2012 & 2013 & 2014 & 2015 & 2016 \\
\hline Agriculture & 1,484 & 2,873 & 6,721 & 6,062 & 11,089 & 18,894 \\
\hline Industry & 5,531 & 4,577 & 5,487 & 5,156 & 7,899 & 9,571 \\
\hline Exports & 865 & 1,066 & 2,259 & 1,772 & 2,231 & 1,629 \\
\hline Storage \& Transport & 1,421 & 1,636 & 3,434 & 2,237 & 2,508 & 3,456 \\
\hline Social Development* & 582 & - & - & - & - & - \\
\hline Local Trade & 3,763 & 4,168 & 4,369 & 6,588 & 9,929 & 16,627 \\
\hline Energy \& Mining & 521 & 129 & 488 & 610 & 401 & 942 \\
\hline Construction & 991 & 2,153 & 3,042 & 3,848 & 5,937 & 9,874 \\
\hline Imports & 2,563 & 1,260 & 1,886 & 2,968 & 1,569 & 3,013 \\
\hline Others & 5,608 & 6,240 & 6,136 & 9,437 & 12,630 & 19,351 \\
\hline Total of Flows: & 23,329 & 24,103 & 33,822 & 38,679 & 54,193 & 83,355 \\
\hline
\end{tabular}

* Social development sector included in other sectors since January 2012

Note: Amounts in nominal values.

Source: Domestic Credit Flows Data received by the Central Bank of Sudan.

In 2007, the CBoS established a Microfinance Unit (MFU) as an independent unit entrusted with designing microfinance policies and developing socioeconomic banking to alleviate poverty and achieve balanced economic development. The unit established a regulatory framework, a microfinance strategy, a High Council for Microfinance, and has licensed about 37 microfinance institutions at federal and state levels as of 2017. Microfinance could be a source of attracting foreign flows. The MFU supports development of own resources of microfinance institutions. The MFU has established partnership with the IsDB and the Arab Fund for Economic and Social Development (a programme of USD 50 million under implementation in collaboration with the Arab Fund). The CBoS policy for 2018 made it mandatory for commercial banks to allocate not less than $15 \%$ of their actual financing portfolio to microfinance, medium and small-scale financing as retail or wholesale financing. In regards to allocation of microfinance per sector.

\section{Public-Private Partnerships}

Public-Private Partnerships have the potential to orient private finance and investment to flow into areas where significant impacts can be made in terms of development. Sudan has realized this potential and 
recently incorporated PPP in its development plan (the Five-Year Programme for Economic Reform 20152019).

The MoFEP has established a PPP unit within the ministry, reporting to the Undersecretary. The mandate of the unit is to work closely with the private sector to prepare the regulatory framework, project priorities, and supervision for PPP activities. Three PPP projects have been undertaken in Sudan in the telecommunications, transport, and water sectors. A notable PPP project is the Omdurman water supply and optimization project, a design-build-operate-transfer contract between a private company (Al Manara Water Company) and the Khartoum State Water Corporation. The unit is in the process of developing concept notes for several PPP projects in power, roads, railways, and health.

Furthermore, in consultation with the private sector, the PPP unit has drafted a PPP law, which was approved by the Ministerial Committees of the Cabinet and forwarded to the Cabinet for approval. It will subsequently be submitted to the National Assembly for ratification, a process that is expected to be finalized by mid-2018. The law heavily draws on international best practices of PPP regulatory frameworks. To support the public-private relations, the Government has also created a Public-Private Dialogue mechanism to bridge the trust gap between the two parties. The mechanism, at the technical level, is organized under a technical committee co-chaired by the Undersecretary of Planning in MoFEP, the Secretary General of the Sudanese Businessmen and Employers Federation (SBEF), and a ministerial committee co-chaired by Minister of Finance and Economic Planning, and the Chairman of the SBEF. These committees include relevant representation from the government line agencies and SBEF chambers.

\section{Corporate Social Responsibility}

There is an active network of companies with Corporate Social Responsibility activities, mostly focused on infrastructure such as hospitals, clinics, schools, and water wells. However, many of these efforts are scattered, unevenly distributed, duplicated and sometimes unsustainable. In an effort to organize CSR and ensure that it is linked to the institutions that are expected to sustain its efforts, the Government is undertaking major steps in this direction.

The President formed in January 2015 a High Council for Corporate Social Responsibility whose mandate includes: i) disseminating and promoting the concept of the social responsibility, taking into account the Sudanese values and traditions; ii) promoting transparency and accountability; iii) determining priorities of interventions and coordinating interventions provided by the private sector under the social responsibility; iv) ensuring equitable distribution and sustainability; and v) protecting the environment and cementing the relation between the Government, the private sector and the civil society.

The High Council is chaired by the First Vice President and co-chaired by the Minister of Security and Social Development. The Council includes relevant ministries, the SBEF, telecommunications and mining companies, major government companies, workers union, representatives of academia and other civil society representatives. The Council convenes annual conferences in a different state within the country, with active participation from the main enterprises. The most recent activity was the 6th Conference hosted by the Gadarief state in October 2017.

Sudan has a Global Compact Network, which was officially registered under the Ministry of Social Security and Social Development Registrar General for Voluntary and Humanitarian Work since 2008 with membership from businesses, NGOs, unions and academia. The Network is housed in a dedicated office in the SBEF premises. The role of the network includes, besides sharing corporate practices and engages in partnership projects with UN agencies, the support for action-oriented policy dialogues on financial markets and CSR.

Sudan is yet to develop a legislative framework to promote CSR and enact additional policies including CSR-related tax credits. In addition, it is also important for MoFEP to cost budgets for these infrastructure projects so that ongoing costs (staffing, maintenance etc.) can be ensured.

\section{External Public Finance \\ Official Development Assistance}

ODA in Sudan has fluctuated significantly since 2012. The United States of America remains the most significant donor in Sudan; however, amounts of assistance continue to decline and remain focused on humanitarian food aid. In the same way, many other DAC donors are decreasing their assistance to Sudan. There is an overreliance on humanitarian financing in Sudan, with humanitarian aid making up 56\% of all ODA to Sudan from 2005 to 2015 , which amounted to USD 16.4 billion. 
Table-6: Financing in Foreign Currencies: Amounts of ODA, FDI and Remittances (2011-2016) (in million USD)

\begin{tabular}{|l|l|l|l|}
\hline Year / Flow & ODA & FDI & Remittances \\
\hline $\mathbf{2 0 1 1}$ & 1742.40 & 2313.70 & 437.60 \\
\hline $\mathbf{2 0 1 2}$ & 1369.13 & 2312.90 & 401.40 \\
\hline $\mathbf{2 0 1 3}$ & 1507.33 & 2179.10 & 424.00 \\
\hline $\mathbf{2 0 1 4}$ & 874.68 & 1251.30 & 314.10 \\
\hline $\mathbf{2 0 1 5}$ & 899.78 & 1728.40 & 149.10 \\
\hline $\mathbf{2 0 1 6}$ & 810.40 & 1063.80 & 153.40 \\
\hline
\end{tabular}

Note: Amounts in nominal values.

Source: World Bank data for ODA, FDI and Remittances from the annual reports (Balance of Payments tables) (20112016); Data received from the Central Bank of Sudan.

Table 7: Total Aid (Development and Humanitarian) to Sudan (2005-2015) (in billion USD)

\begin{tabular}{|l|l|l|}
\hline Type of Aid & Amount in billion USD & \% of Total Amount of Aid \\
\hline Humanitarian Aid & 9.2 & $56 \%$ \\
\hline Loans & 3.8 & $23 \%$ \\
\hline Development Grants & 3.4 & $21 \%$ \\
\hline Total & $\mathbf{1 6 . 4}$ & $\mathbf{1 0 0 \%}$ \\
\hline
\end{tabular}

Note: Amounts in nominal values.

Source: Ministry of International Cooperation, Foreign Aid Report (2016).

There are challenges to gather comprehensive information on ODA in Sudan; there is more than one information system and these information systems need to be integrated to give a comprehensive and updated picture of various types of ODA in the country (Sudan Aid Information Database of MIC, MoFEP System, $\mathrm{CBoS}$, and the Humanitarian Aid Systems). There is also a need to streamline the information systems through which data is shared by development partners with the Government, as well as the need to reflect the ODA in budgets in line with the macroeconomic programme. Furthermore, the predictability of ODA flows in Sudan is poor, restricting forward planning and making programme and project implementation difficult.

Requirements to enhance the flow of ODA to Sudan include reforms in public financial systems and enhancements of internal auditing systems, government aid coordination, coordination and dialogue with international development partners, and South-South cooperation. The overall vision driving all these reforms should be to move from an aid effectiveness approach to a development effectiveness approach to ODA.

ODA from bilateral cooperation make up the majority of development ODA flows from technical cooperation in Sudan, followed by the multilaterals, and the international non-governmental organizations. In 2015 , the UAE provided some general budget supportrelated aid. Moreover, an estimated USD 2.5 billion has been deposited in the CBoS in 2016 and 2017 by Gulf States including Saudi Arabia, Kuwait, and Qatar.

Efforts to solve the debt issue through the HIPC Initiative and removing Sudan off the US list of "State Sponsors of Terrorism" (SSTL) would allow donors to deploy the full range of financial instruments from their tool boxes and pave the way for government arrangements with creditors to use significant tools, such as access to World Bank International Development Association funds. Development programming and finance tools, especially on private sector engagement, infrastructure, and stepping up technical assistance could be further explored. To this end, there may also be a scope for strengthening coordination between the traditional donors and nonDAC donors who are increasing their investment portfolios.

\section{External Private Finance \\ Foreign Direct Investment}

The total flow of FDI into Sudan has fluctuated between USD 2.3 billion in 2011, USD 1.5 billion in 2014, USD 1.7 billion in 2015, and USD 1.06 billion in 2016. The 2015 Investment Policy Review of the United Nations Conference on Trade and Development (UNCTAD) noted that there is a significant potential to attract foreign investors, but it is largely unexploited. UNCTAD pointed out that reassuring and rebuilding the trust of investors is essential to attracting FDI, with particular attention to building a transparent and predictable business environment. Sudan ranked 170 out of 190 economies in the 2018 "Doing Business Report". GoS is aware of the importance of Ease of Doing Business indicators in promoting private investments. Sudan's low ranking in the Ease of Doing Business scale, which deteriorated to as of 168th place in 2016, has drawn the attention of GoS for a serious review. In 2017, GoS formed a technical committee, under the supervision of the State Minister of the Ministry of Investment, to reform the indicators in addition to a high level presidential committee headed by the Prime Minister as an oversight for this reform. Ten technical committees, one for each of the ten indicators of doing business, were formed, including relevant units, and are currently active. 
Furthermore, Sudan has made efforts to diversify the economy and attract FDI into new industries. These efforts include putting in place a relatively open investment legislative framework with several of the existing laws being modernized and in line with good practices. However, implementation is inhibited by lack of secondary legislations, such as environment protection, insufficient competition regulations, insufficient institutional capacity, and little coordination among various levels of government. Key remaining policy gaps also include the need to clarify and streamline the process of investment establishment, as well as access to land, and the review of tax regimes to generate much needed public revenue.

Additional complications were posed by sanctions, which generally prohibited international business from engaging in importing from or exporting to Sudan, or engaging in financial transactions with the GoS. The decision by the US government to lift sanctions could help unlock the potential for the country to tap into its rich mineral and natural resources.

\section{Remittances}

Personal remittances through the official banking system to Sudan have declined significantly, from USD 437.6 million in 2011 to USD 153.4 million in 2016. It is reported that this decline is due to the difference between the official exchange rate and the parallel market rate, meaning that significant amounts are transmitted informally, denying the official channels in the country the benefits of foreign currency reserves. The true size of remittances, including unrecorded flows through formal and informal channels, is believed to be large. For example, the comparison between the average amounts of remittances transferred during the oil boom, where the banks were extensively used, and those transferred in the period 2012-2013 indicate that an important amount, exceeding USD 1 billion, has been transferred to the informal exchange market. However, enforcement actions of the US sanctions complicated bank transfer operations and this resulted in rising difficulties in international transactions, including remittances, which resulted in greater reliance on cash transactions and their associated risks.

Since January 2018, the CBoS has unified the exchange rate and effectively started to apply a managed floating exchange rate system to attract more resources. The $\mathrm{CBoS}$ announces, on a daily basis, an indicative exchange rate with an upper and a lower band within which the commercial banks and exchange bureaus have to declare their daily selling and buying prices of foreign exchange. The indicative rate takes into consideration the incentive rate for exporters and Sudanese citizens working abroad. The indicative exchange rate has currently almost eliminated the gap between the official market rate and the parallel rate, though a parallel market still exists. The CBoS further instructed all banks in Sudan to hand over remittances by Sudanese expatriates abroad in the same currency of the transfer to facilitate the flow of Sudanese remittances from abroad. Nonetheless, the intensification of security risks in the Middle East, where a significant number of Sudanese expatriates are working, poses a high risk of lower remittances in the future and weaker external balance leading to lower growth. Possible responses to this risk could be to strengthen domestic revenue mobilization to increase social safety nets and to organize international financing to support refugees.

\section{Key Financing Challenges and Considerations}

The lack of progress on debt relief and the continuous high debt ratios has caused Sudan to be in debt distress. The weakened external position due to negative terms-of-trade shocks, loss of oil revenue, and the widening fiscal deficit render access to external financing challenging.

Sudan remains a highly indebted country with large external arrears. At the end of 2015, its external debt reached USD 50 billion (61\% of GDP) in nominal terms with $84 \%$ of the total external debt in arrears. Most of the external debt is public or publicly guaranteed, owed mainly to bilateral creditors and almost equally divided between Paris Club and nonParis Club creditors.42 In November 2016, Sudan and South Sudan extended, for two years, their 2012 agreement on debt apportionment whereby Sudan retains all the external liabilities after the secession of South Sudan provided that the international community gives firm commitments on the delivery of debt relief within two years. Without such commitment, Sudan's external debt would be portioned out with South Sudan based on a formula that has not been determined.

The country is eligible for debt relief under the HIPC Initiative. However, Sudan's debt relief prospects hinge on: (i) efforts with the USA to remove Sudan from the SSTL (the list is blocking progress towards badly needed debt relief); (ii) obtaining assurances of support from key creditors, which requires augmented outreach efforts to all the creditors to gather broad support for debt relief; (iii) continuing to cooperate with the IMF aiming at establishing a track record of sound macroeconomic policies; and (iv) developing a fullfledged PRSP.

The scale and ambition of the SDGs requires more and better resources from public, private, domestic and international sources. The preliminary review of overall sources of financing in Sudan points out specific areas to be explored further in a comprehensive DFA. Although this preliminary DFA is presenting an initial diagnosis of the financing framework and financing flows, the prospective comprehensive DFA is expected to present a comprehensive diagnosis of the extent of coherence between the planning and financing systems. The 
assessment, using the INFF approach, should bear particular emphasis on the congruence between the country's development planning and results frameworks and financing policies. Thus, it will be focusing on understanding the characteristics of various financing policies and the degree of alignment of financing flows with national sustainable development results and targets.

\section{Financing of the Agriculture Sector}

Agriculture is a development priority with special importance to Sudan. In 2012, Sudan adopted its I-PRSP that seeks to reduce poverty through rapid and sustainable shared economic growth; agriculture being one of the four pillars of the I-PRSP. Moreover, the 2016 UNDP and GoS SDGs MAPS mission identified agriculture as an accelerator for the achievement of the SDGs in the country. From 2011 to 2014, the agricultural sector contributed on average about $32 \%$ to the country's GDP. Most of Sudan's population (66\%) lives in rural areas where agriculture is the mainstay of people's income and livelihood, and employs around $60 \%$ of the labour force in Sudan. More than half of the value of agricultural production has traditionally come from the livestock sector. Crops are another important type of agricultural activity, mainly in the rain-fed traditional sector, followed by the irrigated sector. The value of agricultural production in 2014 reached SDG 139,516.2 million.

In this context, the GoS has developed and endorsed the Sudan National Agriculture Investment Plan for 2016-2020 (SUDNAIP). The plan has been developed with the vision for agriculture to lead national socioeconomic development. The objective is for agriculture to become capable of rapid and sustainable growth, inclusive of smallholders and with strong linkages to agricultural industrialization. This vision will guide public actions and investments in the agricultural sector over the next five years.

\section{Financing and Budgeting for the SUDNAIP}

Financing and the implementation of the SUDNAIP was planned taking into account the current resource constraints that are connected to the many challenges facing Sudan, which limit its ability to raise substantial revenues or have access to large foreign investment funding.

One of the areas that require special attention in financing the SUDNAIP will be the investment to states given the fact of decentralized governance in Sudan; hence, the Government should consider innovative options as an incentive for directing state funds into the SUDNAIP priorities. These options may include the use of specific purpose or "block grants" accompanied in some cases by matching grants. The modalities, areas, and operationalization of these options, as well as the required constitutional or legal reform required for implementation, will need to be studied in the comprehensive DFA. Innovative financial mechanisms for investment are planned to draw on similar experiences and success stories in African and other countries.

The Seven Investment Programme Areas, which constitutes the SUDNAIP strategic interventions, have been divided into several components. For each component, specific quantitative output targets were identified. The budget of the SUDNAIP was based on multiplying the targeted quantitative output of each subcomponent by the unit cost of each quantitative target to derive the total cost of the components and subsequently the total cost of the investments programme areas.

To safeguard against fluctuations of the exchange rate, all costing data are designated in SDG but converted into USD at the prevailing exchange rate to get the cost at fixed prices. The total agriculture investment requirements for the years 2016-2020 are estimated at USD 5,542 million (with average investment requirements of about USD 1.1 billion per year).

The financing sources will be provided by the Government, private sector, and donors. The budget does not take into account private investment at farm level, which constitutes the major of all agricultural investments, since this source of investment funding is difficult to plan and monitor. The remaining gap was discussed with international development partners in October 2016 during a meeting and pledges are currently being followed up by the Government. The government resources will include both domestic funding and loans to be provided mainly by the Arab Fund, the IDB, and bilaterally by China. The Government's financial commitments are documented in the Five-Year Plan 2015-2019 from which the strategic investments of the SUDNAIP were drawn. The Government's expected resource availability is derived by applying the growth rate in agriculture as envisaged in the government plan (about 7\%).

Out of the total SUDNAIP budget of USD 5,542 million, it is estimated that there will be a funding gap of USD 632 million. The Government will have the biggest share in the SUDNAIP funding $(66 \%)$ whereas the private sector is planned to amount to about $23 \%$ leaving a funding gap of around $11 \%$ of the SUDNAIP.

In terms of investment areas for which the Government will require donors support, the major funding gaps are in capacity development, institutional reforms, and studies for enabling environment (IPA 1 and 2). The funding gap will also affect food security such as investments in improved crop varieties, sustainable soil and water management, water harvesting, and other low risk technologies (IPA 3 and 7). Furthermore, the gap will be in natural resources 
(IPA 6) including prevention of land degradation, forest management using local communities, rangeland conservation and rehabilitation, pasture seeds spreading, and demarcation of the stock routes to avoid conflict between nomads and settled farmers.

\section{Development of an Integrated National Financing Framework for Sudan}

The AAAA called for cohesive, nationally owned, sustainable development strategies to be supported by INFFs. The INFF can be understood as a system of policies and institutional structures that can help governments to achieve development goals through improved management of diverse sources of financing. It does this by improving alignment and integration between development planning and financing systems, and creating mechanisms to bring together stakeholders to improve coherence. A conceptual model for understanding and assessing INFF has been developed covering six building blocks of INFFs:

1. Leadership and institutional coherence: leadership from the highest levels of government to bring together key actors and build an integrated, aligned approach to mobilizing the investments necessary to achieve the country's goals.

2. Vision for results: the foundation of an INFF is clarity on the direction and desired outcomes that the country wants to achieve long-term.

3. Overarching finance strategy: a strategic financing policy takes the vision for results, develops estimates for the costs and types of investments needed and provides long-term direction to guide operational policies that aim to mobilize investments from each type of financing.

4. Specific financing policies: operational financing policies are the annual and medium-term plans that invest public finance and aim to mobilize and stimulate investments from other actors. There is typically a matrix of policies; some, such as the budget or national international cooperation strategy, will be focused on a specific type of finance, while others will focus on sector or thematic objectives, including strategies on financing in those areas. In an INFF these build on and contribute to the direction provided in the vision for results and strategic financing policy.

5. Monitoring and evaluation: a monitoring, evaluation and learning system helps the Government to plan the outcomes it wants to achieve, the contributions that different types of financing can make, and to monitor progress for more effective implementation.

6. Accountability And Dialogue: Strong participatory processes for accountability and dialogue help build the trust necessary to mobilize contributions from stakeholders outside the Government, make sure policies are designed and delivered effectively, and ensure a voice for citizens, civil society, business, development partners, and other actors in development.

\section{Preliminary Assessment of INFF Blocks in Sudan}

The sequence of the comprehensive DFA approach is that the assessment will first map out the Government's financing framework and linkages between planning and financing systems in order to build a full understanding of its building blocks. This is an important step since it has a comparative advantage of following a holistic, top-down perspective. As the mapping exercise develops and the existing building blocks of the financing framework and linkages between them are understood, a more detailed assessment of key building blocks can be commenced, focusing on a strategic development plan, a strategic financing policy, and operational financing policies. After this step, recommendations about moving towards an INFF are made. The mapping exercise in the DFA also analyses the existing institutional arrangements/mechanisms for implementing a development plan and financing policies, recommendations can also be made regarding accountability and dialogue, focusing on development coordination mechanisms, dialogue platforms, and improving transparency to support evidence-based dialogue.

\section{Leadership \\ Vision for Results}

At the leadership level of the potential INFF in Sudan, the vision of the Twenty-Five-Year Strategic Plan of the NCSP, and the four/five-year plans derived from it, represents the intended results. The link between the four-year plan (2017-2021) and the National Programme for SDGs also plays an important role at this level.

GoS is taking measures to mainstream and localize the SDGs in synergy with funding to financing. The "National Mechanism to Supervise the Sustainable Development Goals" led by the Vice-President is tasked to coordinate implementation of the SDGs at national, state, and local levels, and explore various sources of development financing.

There is an overarching process for a national strategic plan in addition to several sectorial strategies. The substantive/analytical linkages across various areas/sectors need to be expanded.

\section{Strategic Financing Policy}

Budgeting for the five-year strategic plans is explained in the preceding part of this report on the financing framework for development in Sudan. The focus of the Twenty-Five-Year National Strategy sets a broad direction for the results that the country wants to achieve. It does not yet provide a comprehensive framework for long-term financing plans. 
MoFEP's Five-Year Programme of Economic Reform 2015-2019 aims to "achieve, sustain and strengthen stability of economic factors, and then to achieve high, sustainable and inclusive economic growth rates and target to open more job opportunities for transforming the economy to the expansion of the production base stage"

\section{Operational Financing Policies}

Delivery of the Government's financing strategy in practice takes place through a series of operational policies. Some of these, such as the budget or national aid policies, focus explicitly on a particular type of finance (it is worth mentioning here that Sudan is in the process of endorsing its first international cooperation strategy with a vision to enhance its development cooperation with international development partners). Other financing strategies focus on themes such as the prospective PRSP and the agriculture sector development plan (e.g. SUDNAIP).

The effectiveness of the Government's overall approach to financing across all resources depends on how comprehensive these policies are across all types of financing, how effectively they build on the longterm guidance of the four-year plan in defining their focus, and the strengths of mechanisms to align and coordinate across operational policies and between operational and long-term policies.

The prospective full-fledged DFA will assess this by looking at the degree of alignment of existing operational policies with national development results, and take prospective flow analysis to outline whether existing operational policies are on the right track, need acceleration, or changes in policy direction.

In terms of public finance, both the budgeting process and revenue collection are managed by MoFEP. Some areas that will need more information/understanding include:

- The public expenditure orientation (expenditure across sectors/themes, capital vs current, states vs central etc.);

- Tax policy and associated reforms; and

- Policy related to non-tax revenue such as oil revenue, natural resource-based revenue etc.

\section{Monitoring and Evaluation}

Monitoring and accountability for national, subnational, and sectoral development results and their financing could be improved within the current structure and tools through developing well-articulated indicators and involving a broader group of stakeholders. Integration of development and sectoral resources information management systems and international non-governmental organizations and local civil society could all be useful in monitoring and reporting impact on the ground and feeding this information back to some sort of multi-stakeholder platform. Capacity development investments will be needed before this can take place.

\section{Accountability and Dialogue}

Strong mechanisms for dialogue are essential for building trust and shared ownership over financing policies with the non-state actors whose contributions the Government aims to mobilize toward long-term plans. More analysis is needed in the full DFA on the national multi-stakeholder dialogue mechanisms with the private sector (such as the Public-Private Dialogue) as well as existing and planned dialogue and coordination mechanisms between government, development partners and civil society.

\section{Development Cooperation}

In view of the fragmentation in aid architecture and the multiplicity of actors in aid delivery, and the various government line agencies implementing aid projects; the Government has prepared an International Cooperation Strategy. The goal of the Strategy is to support cooperation between the Government and its development partners to coordinate external assistance and to facilitate aid planning, monitoring and evaluation mechanisms in line with the National Development Frameworks as well as to ensure complementary and synergy among government institutions.

MIC, being the duly mandated institution in the Government of Sudan for aid coordination, was a principal interlocutor for the preparation of the International Cooperating Strategy for Sudan. The Strategy, prepared in close cooperation with the key government Aid Management institutions, was carried out through a comprehensive consultative process within the Government and with the international partners

The Strategy was based on the Government's Twenty-Five Years National Strategy (2007-2031), the Five Years Plan (2015-2020), the Paris Declaration for Aid Effectiveness, Busan Partnership for Effective Development Cooperation (2011), the Accra Agenda for Action (2008), and other government programs and agreements to which Sudan is a party.

The Strategy has set up a new institutional architecture and a system to monitor aid flows in order to improve the efficiency of aid management. The mandates and roles of key government institutions in the country were identified and clarified, and the donor landscape was specified. The Aid Strategy incorporated an aid coordination system to be anchored around a number of dialogue and coordination mechanisms, both within government ministries and between these ministries and donor groups, to improve communication and aid effectiveness. To complete the aid coordination architecture, the non-traditional donors (Arab countries, China, India etc.), in addition to South-South Cooperation, are playing an increasing role, although 
their modalities are quite different from the other agencies. Therefore, the strategy advocated their inclusion in the coordination set up. The Strategy also assigned special emphasis on coordination for the private sector and the civil society.

The dialogue encompasses general macro issues as well sectoral and thematic issues. The dialogue centers on the following thematic and sectoral issues; i) Peace and Stability, ii) Economic Development and Reforms, iii) the SDGs, iv) Climate Change, v) Refugees and Immigration, vi) and External Debt. It is expected that the dialogue will be further anchored to the Poverty Reduction Strategy Paper, which is currently under preparation.

\section{Private Sector Development and Investment Regime}

More research and analysis needs to be undertaken on the business environment, private sector development strategy, investment policy etc. Sudan is neighboring seven countries, four of which are landlocked (Ethiopia, South Sudan, Central Africa Republic and Chad). Considerable gains and resources for both the private sector and the country as a whole could be realized from boosting border trade with these countries.

\section{SUMMARY OF RECOMMENDATIONS}

This preliminary DFA intended to present the DFA concepts contextualized for Sudan to promote the future undertaking of a comprehensive DFA. It discussed only some of the financing flows due to the preliminary nature of the study, the short timeline for the assessment, and data availability factors.

Several institutions, agencies and stakeholders are involved in the field of development finance. The experience in Sudan has shown that insufficient coordination leads to considerable waste of resources that are badly needed to finance development. An example is the corporate social responsibility, which is not coordinated and lacks a governing body, leading to scattered efforts and inefficient resource use. Therefore, attention must be placed on strengthening coordination to avoid duplication and mandate overlaps, at the same time recognizing the defined roles and responsibilities for the various agencies and the involvement of different stakeholders. This will require, after reviewing the mandates of the various agencies engaged in development finance, designing mechanisms for coordination that will bring together all stakeholders to improve coherence. It is essential in this coordination to bring all stakeholders on board from the very beginning of the planning process to ensure their commitments later. The methodology of preparing this preliminary document, with participation of stakeholders, is a step in this direction.

Improving data availability and quality on development finance flows and planning has also emerged as requirements for improving development finance. Considerable efforts are needed to improve the production of data by official sources to ensure data reliability at both national and sub-national levels. In this context, capacities of the CBS should be strengthened to play a more effective role in data production and collection.

Although finance is one constraint for the achievement of the SDGs, so is the absorptive capacity to utilize the financing that is available. The AAAA and the 2030 Agenda recognize capacity development requirements for development finance. Capacity development is needed at all stages including public sector planning and management systems, procedures to utilize available resources, monitoring and evaluation as well as learning to work with non-state partners in delivery of public services and PPP arrangements. Capacity development should support all institutional and non-institutional stakeholders, including civil society and the business sector.

With regard to comprehensiveness and coverage of analyses, some stakeholders such as the informal sector, the Social Security Investment Fund, CSR, and new emerging sectors in the economy such as tourism were not reflected in figures; they should be studied within the context of developing the INFF.

\section{The Way Forward}

The prospective comprehensive DFA is proposed to:

- Study the building blocks of the prospective Sudan INFF.

- Cost the SDGs and the formulation of the PRSP.

- Present amounts in real terms, rather than nominal, to give an in-depth view of the trends in the financing flows.

- Finalize an agreement on the scope of a comprehensive DFA by the oversight committee. A technical team of four members is expected to undertake the comprehensive study within an estimated period of one year.

\section{Domestic Public Finance}

- Study the prospects of tax reforms.

- Study the potential for Zakat to reinforce its development impact through capacity development, exchange of lessons learned, and harmonization between the targeting systems of Zakat and national economic empowerment initiatives.

- Undertake an in-depth analysis of the informal sector, Social Security Investment Fund and emerging sectors in the economy with revenue potential generation like tourism.

\section{Domestic Private Finance}

- Analyze and recommend how to promote the private sector considering the diversity of the 
sector ranging from small producers and cooperatives to large companies.

- Review public policy and how it could create an enabling environment for the private sector.

- Analyze the flows of microfinance to the private sector and other target groups and study the degree of control the Government has on re-orienting domestic private finance flows.

- Study the alignment of domestic investment with the SDGs and national development goals and targets.

- Cover the national multi-stakeholder dialogue mechanisms with the private sector (such as the Public-Private Dialogue) as well as existing and planned dialogue and coordination mechanisms between government, development partners, and civil society.

- Study the harmonization and integration of CSR interventions by private sector investments, international community, and the Government.

- Study the potential for PPPs.

\section{External Public Finance}

- Study the debt issue and the HIPC Initiative from the perspective of its effect on ODA financing flows and provide guidance on the way forward that would enable Sudan to access concessional loans offered by international organizations.

- Study the challenges ODA faces and the obstacles hindering the realization of its full potential.

\section{External Private Finance}

- Analyze, informed by the ongoing reform of Ease of Doing Business supervised by the Ministry of Investments, whether an enabling environment is ensured for the FDI.

- Address the issue of safeguarding against fluctuations of the exchange rate (the case of the SUDNAIP costing can be used as an experience in this regard).

\section{Glossary}

Climate Finance: Climate finance aims at reducing emissions and enhancing sinks of greenhouse gases and aims at reducing vulnerability of, and maintaining and increasing the resilience of, human and ecological systems to negative climate change impacts.

Concessional and non-concessional lending: While non-concessional loans are provided at, or near to, market terms, concessional loans are provided at softer terms than market terms. A concessional loan is a loan with a grant element. Conceptually, the measure of concessionality, or grant element, involves calculating the difference between the face value of a loan and the present value (or economic value) of debt service repayments, expressed as a percentage of the face value of a loan. For the purposes of classifying ODA, loans have been categorized as concessional by the OECD if their grant element exceeds $25 \%$, using a fixed $10 \%$ discount rate in the present value calculation.

Corporate Social Responsibility: The responsibility of an organization for the impacts of its decisions and activities on society and the environment.

Development Assistance Committee: The committee of the Organization for Economic Co-operation and Development which deals with development cooperation matters. A description of its aims and a list of its members are available at www.oecd.org/dac.

Direct Taxes: Direct taxes in Sudan include personal income tax, tax on corporate income, business profit tax, tax on rent, tax on capital profit, development tax on business and capital profits.

Domestic Resource Mobilization: It is the way in which countries raise and spend their own funds to address the needs of their citizens. Increasing taxes and other income into government treasuries, improving tax policy and cracking down on the misuse of funds can all be part of domestic resource mobilization. Domestic resource mobilization is critical to funding the SDGs. It was a key focus of the 2015 financing for Development conference in Addis Ababa, Ethiopia, and continues to be a part of global conversations about funding the goals.

Domestic Credit: The part of an increase in the amount of money in a country's economy that includes bank loans and the money the Government borrows to finance its activities: the main contributor to the domestic credit expansion is government borrowing for budgetary support.

Domestic Credit to Private Sector: Refers to financial resources provided to the private sector by financial corporations, such as through loans, purchases of no equity securities, and trade credits and other accounts receivable that establish a claim for repayment.

Domestic Finance: Borrowing from the Central Bank, Commercial Banks Letters of Guarantees and Government Treasury (or Musharaka) and Investment Certificates.

Excise Duty: A domestic tax on the sale or production for sale of specific goods. Excises can be applied to both imported and domestic goods, but are distinguished from customs duties, which are taxes on imports. 
Foreign Finance: Foreign Finance is financing provided through loans and other official flows from external sources.

Foreign Direct Investment: Direct investment equity flows into the reporting economy. It is the sum of equity capital, reinvestment of earnings, and other capital flows. Direct investment is a category of crossborder investment associated with a resident in one economy having control or a significant degree of influence on the management of an enterprise that is resident in another economy. Ownership of $10 \%$ or more of the ordinary shares of voting stock is the criterion for determining the existence of a direct investment relationship.

Gross Domestic Product: An aggregate measure of production equal to the sum of the gross values added of all resident and institutional units engaged in production (plus any taxes, and minus any subsidies, on products not included in the value of their outputs).

Indirect Tax: Indirect taxes in Sudan include import duties, excise tax, consumption and sales tax, defense tax on import, development tax on import and export and industrial, export duties and export royalties, sugar monopoly profit, fees on remittances to abroad, licenses, licenses and VAT.

LDCs: Least developed countries, a group established by the United Nations. To be classified as LDCs, countries must fall below thresholds established for income, economic diversification and social development. The DAC List of ODA Recipients is updated immediately to reflect any change in the LDCs group.

LMICs: Lower middle-income countries, i.e. those with GNI per capita between USD 1,006 and USD 3,975 in 2010. LDCs which are also LMICs are only shown as LDCs, not as LMICs.

Net Present Value of Debt: The nominal amount outstanding minus the sum of all future debt-service obligations (interest and principal) on existing debt discounted at an interest rate different from the contracted rate.

Non-Tax Revenue: Revenue receipts which are not generated by taxing the public. Money which the Government earns as "dividends and profits" from its profit making public enterprises (PSUs). Interest which the Government earns on the money lent by it to external or internal borrowers.

Official Development Assistance: Those flows to countries and territories on the (Development Assistance Committee) list of ODA Recipients and to multilateral institutions which are: i. provided by official agencies, including state and local governments, or by their executive agencies; and ii. each transaction of which: a) is administered with the promotion of the economic development and welfare of developing countries as its main objective; and b) is concessional in character and conveys a grant element of at least $25 \%$ (calculated at a rate of discount of $10 \%$ ).

Other Official Flows: Transactions by the official sector with countries on the DAC list of ODA recipients which do not meet the conditions for eligibility as ODA, either because they are not primarily aimed at development or because they have a grant element of less than $25 \%$.

ODA Loans (ALSO CREDITS): Transfers for which repayment is required. Only loans with maturities of over one year are included in OECD DAC statistics. Data on net loans include deductions for repayments of principal (but not payment of interest) on earlier loans. This means that when a loan has been fully repaid, its effect on total net ODA over the life of the loan is zero.

Public-Private Partnership: The PPP is a collaborative arrangement between a government authority or public corporation and a private entity regarding the provision of public infrastructure or services. These partnerships are defined and mediated by legally-binding contracts, which clearly establish and allocate responsibilities, risks and rewards between the different parties.

Remittances: Are funds sent by people living and working abroad back to their home countries. In many developing countries remittances are the largest external source of finance, greater than ODA and foreign direct investment.

Tax Base: The measure upon which the assessment or determination of tax liability is based. For example, taxable income is the tax base for income tax and assessed value is the tax base for property taxes.

\section{SOURCES}

1. African Development Bank, Private Sector-Led Economic Diversification and Development in Sudan (2016).

2. Central Bank of Sudan, Annual Reports (Balance of Payments tables) (2011-2016).

3. Central Bureau of Statistics, Multiple Indicator Cluster Survey in Sudan (2014).

4. Central Bureau of Statistics, "National Accounts Report 2011-2014" (2017).

5. Government of Sudan, Sudan National Agricultural Investment Plan (SUDNAIP) (20162020) (2016).

6. International Monetary Fund, "Sudan Staff Report for the 2017 Article VI Consultation" (September 2017).

7. International Monetary Fund, "Sudan Staff Report for the 2017 Article VI Consultation" (September 2017). 
8. National Population Council, Ministry of Social Security and Social Development, "Sudan MDGs 2015 Country Report" (2015).

9. MDG indicator 3.1 Ratios of girls to boys in primary, secondary and tertiary education; National Population Council, Ministry of Social Security and Social Development, Sudan MDGs 2015 Country Report (2015).

10. 14 Sudan I-PRSP Status Report 2016.

11. The Twenty-Five Year National Strategy 20072031 has been detailed into five-year planning cycles; the first was 2007-2011, the second was 2012-2016 and the current cycle is the third one 2017-2020 which is a four-year plan instead of five.

12. Preliminary estimates for 2017 by MoFEP; Ministry of Finance and Economic Planning, Annual Budget Performance Reports (2017).

13. Ministry of Finance and Economic Planning, Five Year Programme for Economic Reform 2015-2019 (2015).

14. International Monetary Fund, "Sudan Staff Report for the 2016 Article VI Consultation" (July 2016).

15. The Zakat Chamber, Annual Performance Report (2016).

16. The exchange rate used is the official exchange rate average in 2015 (June) USD 1 = SDG 6.0.

17. The UN Resident Coordinator's Office supports the UN Resident Coordinator and UN agencies, funds and programmes in strengthening the coordination of development activities within the $\mathrm{UN}$ and between the UN and its partners.

18. Ministry of International Cooperation, Foreign Aid Report (2016).
19. OECD, "Busan High Level Forum on Aid Effectiveness: Proceedings 29 November-1 December 2011" (2011).

20. OECD, Creditor Reporting System (2015).

21. United Nations Development Programme, "Methodological Guidance Note for the DFA and Integrated Financing Solutions" (October 2017).

22. United Nations Development Programme, "SDGs Mainstreaming, Acceleration, Policy Support (MAPS) Mission Report” (December 2016).

23. United Nations, Financing for Development: Progress and Prospects, Report of the InterAgency Task Force on Financing for Development (2017).

24. United Nations, Financing for Development: Progress and Prospects, Report of the InterAgency Task Force on Financing for Development (2017).

25. United Nations, Financing for Development: Progress and Prospects, Report of the InterAgency Task Force on Financing for Development (2017).

26. United Nations Development Programme, "SDGs Mainstreaming, Acceleration, Policy Support (MAPS) Mission Report" (December 2016).

27. United Nations, The Addis Ababa Action Agenda of the Third International Conference on Financing for Development (2015); United Nations Development Programme, "Methodological Guidance Note for the DFA and Integrated Financing Solutions" (October 2017).

28. World Bank, "Doing Business Report" (2018).

29. World Bank Development Indicators.

30. World Bank in Sudan, "Country Overview" (2017). 